\title{
Strength Characteristics of OSB in Bending - Difference between Upper and Lower Panel faces
}

\section{Savojna čvrstoća OSB ploča - razlika između gornje i donje strane ploče}

\author{
Original scientific paper • Izvorni znanstveni rad \\ Received-prispjelo: 2. 11. 2010. \\ Accepted-prihvaćeno: 27. 4. 2011. \\ UDK: $630 * 863.2 ; 674.815$ \\ doi:10.5552/drind.2011.1036
}

\begin{abstract}
This article is focused on evaluating the differences between the upper and lower faces of OSB $/ 3$ - Superfinish in the course of bending stress. OSB is a material manufactured from wood chips of a large surface area, irregular shape and unequal length, which are partly randomly distributed and at the same time not perfectly oriented. Differences regarding the content of OSB surface layers cause unequal properties, which can be demonstrated, especially under bending load. The measurements made show that OSB positioned with upper face downwards in the course of the bending test are capable of withstanding a higher load, and reaching an evidentially lower deflection, compared to those with lower face downwards.
\end{abstract}

Keywords: oriented strand boards (OSB), modulus of elasticity in bending (MOE), maximum deflection, image analysis

SAŽETAK・Rad se bavi procjenom razlika između gornje i donje strane OSB/3 ploča, prije svega u smislu savojnog naprezanja. OSB ploče drvni su materijal proizveden od drvnog iverja velike površine, nepravilnog oblika $i$ nejednake duljine. Drvno je iverje slučajno raspoređeno te stoga nije uvijek potpuno pravilno orijentirano. Razlike u sastavu površinskih slojeva OSB ploča bitno utječu na nejednolikost svojstava ploča, posebice pri opterećenju na savijanje. Provedena mjerenja pokazala su da OSB ploče koje su pri testiranju okrenute gornjom površinom ploče prema dolje mogu podnijeti veća opterećenja na savijanje i bilježe manje deformacije od ploča koje su pri testiranju bile postavljene donjom površinom prema dolje.

Ključne riječi: ploče s orijentiranim iverjem (OSB ploče), modul savojne elastičnosti (MOE), maksimalna deformacija, analiza slike

\section{INTRODUCTION \\ 1. UVOD}

At present, with the rapid development of engineering and technology, the number of wood-based materials is increasing, and the possibilities for their application are being extended. OSB is a state-of-the- art material especially suitable for use in building industry as construction material for walls, roofs and floors, as well as for the manufacture of the so-called "I" beams. OSB is a material manufactured from flat wood chips arranged in layers (usually 3 layers), which are oriented perpendicular to each other and connected under pressure with some water-resistant adhesive. The

\footnotetext{
${ }^{1}$ Authors are assistants at the Czech University of Life Sciences Prague, Faculty of Forestry and Wood Sciences, Prague, Czech Republic.

${ }^{1}$ Autori su asistenti Fakulteta šumarstva i znanosti o drvu Sveučilišta bioloških znanosti u Pragu, Prag, Republika Češka.
} 
orientation of the layers has the same purpose and provides the same advantages as the cross-like bonding of veneer layers used in plywood manufacturing - especially with respect to reducing the anisotropic properties and dimensional changes (Baker, 2002).

For OSB - the same applies to other construction materials used in the building industry - the modulus of elasticity is one of the most important material parameters considered in static designing of structures, and also in dimensioning individual elements.

The modulus of elasticity in bending and the bending strength of OSB are most significantly influenced by the size and geometry of the chips (Suchsland, 1968; Lam, 2001; Nishimura et al., 2004) as well as by the orientation of fibers of individual chips in surface layers (Geimer, 1986; Xu, 2002; Painter et al., 2006a,b), although some other manufacturing factors significantly influence strength characteristics as well, for instance the distribution and shaping of chips during the pressing process (Sharma and Sharon, 1993; Oudjehane et al., 1998), pressing time and pressure (Xu and Winistorfer, 1995; Xu, 1999), interactions between layers (Kamke, 2004), type and quantity of adhesive mixtures used, etc.

Modern technologies for manufacturing OSB strive for very thin and long chips. In general, the optimum dimensions of the chips may be formulated as follows: 0.4 to $0.6 \mathrm{~mm}$ in thickness, 5 to $20 \mathrm{~mm}$ in width, 60 to $120 \mathrm{~mm}$ in length (Peña and Rojas, 2006). The length of chips manufactured by means of a ring splitting machine may reach up to $150 \mathrm{~mm}$. The longest chips - and thus the best quality ones - are used for the surface layers of OSB, while small chips are used for intermediate layers. Using longer and thinner chips, as well as orienting them precisely, increase the strength, rigidity and dimensional stability of panels. Usually, smaller chip fractions (smaller than $6 \mathrm{~mm}$ ) are used for other purposes (Štefka, 2002). The ratio of small wood particles in OSB is usually about $3-10 \%$ (Han et al., 2006, 2007).

For industrially manufactured OSB, the density of the surface layers is higher than the density of the intermediate layer (Xu and Winistorfer, 1995). During bending tests, the greatest tansion is applied to surface layers of the test specimen. Thus it is preferable to manufacture OSB with some "U" shaped density profile along the panel thickness, i.e., the surface layers have a higher density than the intermediate ones. A panel manufactured in this way achieves higher bending stren-

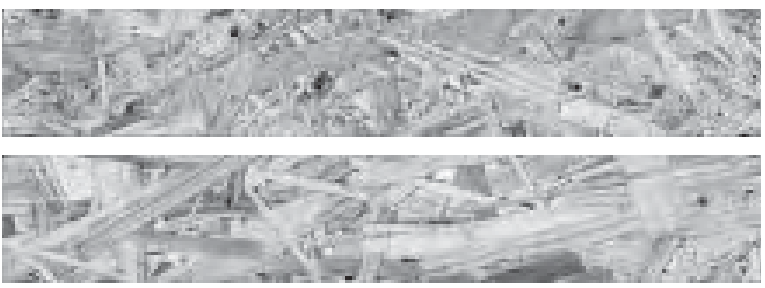

Figure 1 Top view: Lower and upper faces of OSB/3 Superfinish, test specimens of $50 \times 290 \mathrm{~mm}$ - parallel direction

Slika 1. Pogled odozgo: donja i gornja strana OSB/3 ploče izvrsne završne obrade, uzorci dimenzija 50 x $290 \mathrm{~mm}-$ paralelni smjer gth compared to panels with an equal cross density profile, at an identical average OSB density (Painter et al., 2006 ${ }^{\mathrm{a}}$ ).

The advantages of the consequent orientation and equal shaping of the chips are well-known; however, an unequal distribution of chips within the layers of the OSB may take place. During the shaping process and placing of chips, some smaller fractions may penetrate into the lower layers of the chip sandwiches, while the level of their orientation is also reduced. Although no reference of this fact is made in expert literature, for commercially manufactured OSB the lower face may be usually distinguished in some easy way from the upper face. This difference is due to a larger ratio of smaller chips in the lower face of the panels (see Fig. 1).

\section{MATERIAL AND METHODS}

\section{MATERIJAL I METODE}

For the testing measurements, specimens of construction panels of OSB/3 - Superfinish were used (bearing panels to be used in a wet environment in accordance with the requirements of the ČSN EN 300 standard), with the thickness of $12 \mathrm{~mm}$ and average density of $590 \mathrm{~kg} / \mathrm{m}^{3}$. For manufacturing chips, spruce $(80 \%)$ and pine $(20 \%)$ were used. The intermediate layer was bonded with an MDI (isocyanate) adhesive $(3.5 \%)$ and the surface layers were bonded with an MUF (melamine-urea-formaldehyde) adhesive (8.5 $\%$ ). The approximate ratio of surface chips to chips in the intermediate layer was 50/50.

The extraction and preparation of test specimens followed the ČSN EN 326-1 and ČSN EN 310 standards dealing with testing the modulus of elasticity in bending and bending stress.

The test specimens were collected from eight different panels. From each panel, six test specimens were extracted for each of the two main manufacturing directions (96 pieces in total). The specimens were then subdivided into two identical groups, each one containing 24 test specimens for the parallel direction and 24 test specimens for the perpendicular direction. During the testing, the first group was placed onto the supports with lower face downwards, whereas the test specimens of the second group were loaded with lower face upwards.

The MOE (modulus of elasticity) was evaluated using a UTS $100 \mathrm{~K}$ test machine (measuring range of 5 to $100 \mathrm{kN}$ ) in accordance with the ČSN EN 310 (1995) standard. The maximum force needed to break the specimen, the corresponding deflection and the calculation of the modulus of elasticity in bending were processed with Phoenix software (Version 5.04.006, UTS-Testsysteme).

For determining the difference between the upper and lower faces of the panels, an image analysis was made with the software NIS Elements AR. The principle of image analysis consists in creating a copy of an image by means of cameras, visualizing the panel, and analyzing the typical characteristics of individual objects using a computer program. Nowadays, this analysis is primarily used for measuring chip orientation (Xu, 2002; Nishimura et. al., 2002; Nishimura et. 
al., 2004; Painter et. al., 2006 ${ }^{\mathrm{b}}$ ). For the purposes of this article, image analysis was used for calculating the average size and quantity of chips placed in the upper and lower layers of the OSB.

Prior to the test measurements, all test specimens were scanned (scanner Epson GT 15 000, optical resolution of 600). The raster images scanned (6 $855 \mathrm{x}$ 1163 pixels) were vectorized by means of the „Peak Detection" function, and for calculation of the chip area in the upper layer, the „Threshold“ $(0-110)$ and „Cleaning“ (1x) functions were used. All calculations were executed under a color depth of 8 bits.

\section{RESULTS AND DISCUSSION}

\section{REZULTATI I RASPRAVA}

The basic descriptive statistics were computed: arithmetic mean, standard deviation and coefficient of variation, and the range of data were expressed with a maximum and minimum value. The assumption of the measured data normality by a Shapiro-Wilks W test was verified before computing the statistical analysis (using Statistics 8.0 CZ). The results of tests on the modulus of elasticity in bending and the maximum deflection of the OSB/3 are presented in Tables 1 and 2 and Figures 2 and 3.

In the table with results, the values of modulus of elasticity in bending and of bending strength are rounded to three significant figures (in accordance with the
ČSN EN 310 standard). For statistical analysis, unrounded values were used. After computation of the basic statistical indicators, an analysis of the scattering was elaborated (ANOVA), whose results are shown in Fig. 2. For evaluating the significance of differences between the individual groups, multiple comparison tests (Post-Hoc) were carried out.

An analysis of the scattering shows that OSB achieves higher values of the modulus of elasticity in bending if they are loaded with upper face downwards. The differences in value are by no means high, reaching $1.5 \%$ in the parallel direction and $3.4 \%$ in the perpendicular direction. However, the deflection values resulting from maximum load (see Fig. 3) demonstrate a different statement.

As demonstrated in Fig. 3, the deflection of specimens loaded with upper face downwards is $12.5 \%$ lower, in comparison with panels loaded with lower face downwards - in the parallel direction. For the perpendicular direction this difference amounts to $5 \%$. The executed post-hoc test demonstrated different deflections of groups in the parallel direction (Fisher's LSD test, a less stringent test - Tukey's HSD failed to prove a statistically significant difference).

The difference between values of the modulus of elasticity in bending and the maximum deflection between the upper and lower faces of the panels is just on the limit of statistical significance, but the values reached with the upper face are clearly higher. A larger

Table 1 Modulus of elasticity in bending of OSB/3 - Superfinish

Tablica 1. Modul savojne elastičnosti OSB/3 ploča - izvrsne završne obrade

\begin{tabular}{|l|c|c|c|c|c|}
\hline \multirow{2}{*}{} & \multicolumn{4}{|c|}{ Modulus of elasticity in bending, MPa / Modul savojne elastičnosti, MPa } \\
\cline { 2 - 6 } & $\begin{array}{c}\text { Mean } \\
\text { srednji }\end{array}$ & $\begin{array}{c}\text { Minimum } \\
\text { najmanji }\end{array}$ & $\begin{array}{c}\text { Maximum } \\
\text { najveći }\end{array}$ & $\begin{array}{c}\text { Std. Dev. } \\
\text { stand. dev. }\end{array}$ & $\begin{array}{c}\text { Coef. Var. } \\
\text { koef. var. }\end{array}$ \\
\hline $\begin{array}{l}\text { Lower Face - Parallel } \\
\text { Donja strana - paralelno }\end{array}$ & 4760 & 3770 & 6610 & 735 & 15.42 \\
\hline $\begin{array}{l}\text { Upper Face - Parallel } \\
\text { Gornja strana - paralelno }\end{array}$ & 4840 & 3290 & 6700 & 794 & 16.42 \\
\hline $\begin{array}{l}\text { Lower Face - Perpendicular } \\
\text { Donja strana - okomito }\end{array}$ & 2010 & 748 & 2490 & 358 & 17.86 \\
\hline $\begin{array}{l}\text { Upper Face - Perpendicular } \\
\text { Gornja strana - okomito }\end{array}$ & 2080 & 1390 & 4050 & 537 & 25.85 \\
\hline
\end{tabular}

The sample size $n=24$ / veličina uzorka $n=24$

Table 2 Maximum deflection of OSB/3 - Superfinish

Tablica 2. Maksimalna deformacija OSB/3 ploča - izvrsne završne obrade

\begin{tabular}{|l|c|c|c|c|c|}
\hline \multirow{2}{*}{} & \multicolumn{5}{|c|}{ Deflection, mm / Deformacija, mm } \\
\cline { 2 - 6 } & $\begin{array}{c}\text { Mean } \\
\text { srednji }\end{array}$ & $\begin{array}{c}\text { Minimum } \\
\text { najmanji }\end{array}$ & $\begin{array}{c}\text { Maximum } \\
\text { najveći }\end{array}$ & $\begin{array}{c}\text { Std. Dev. } \\
\text { stand. dev. }\end{array}$ & $\begin{array}{c}\text { Coef. Var. } \\
\text { koef. var. }\end{array}$ \\
\hline $\begin{array}{l}\text { Lower Face - Parallel } \\
\text { Donja strana - paralelno }\end{array}$ & 6.502 & 5.218 & 8.219 & 0.724 & 11.14 \\
\hline $\begin{array}{l}\text { Upper Face - Parallel } \\
\text { Gornja strana - paralelno }\end{array}$ & 5.687 & 3.898 & 8.290 & 1.137 & 19.99 \\
\hline $\begin{array}{l}\text { Lower Face - Perpendicular } \\
\text { Donja strana - okomito }\end{array}$ & 8.020 & 5.463 & 10.097 & 1.069 & 13.33 \\
\hline $\begin{array}{l}\text { Upper Face - Perpendicular } \\
\text { Gornja strana - okomito }\end{array}$ & 7.616 & 4.894 & 9.868 & 1.330 & 17.47 \\
\hline
\end{tabular}

The sample size $n=24$ / veličina uzorka $n=24$ 


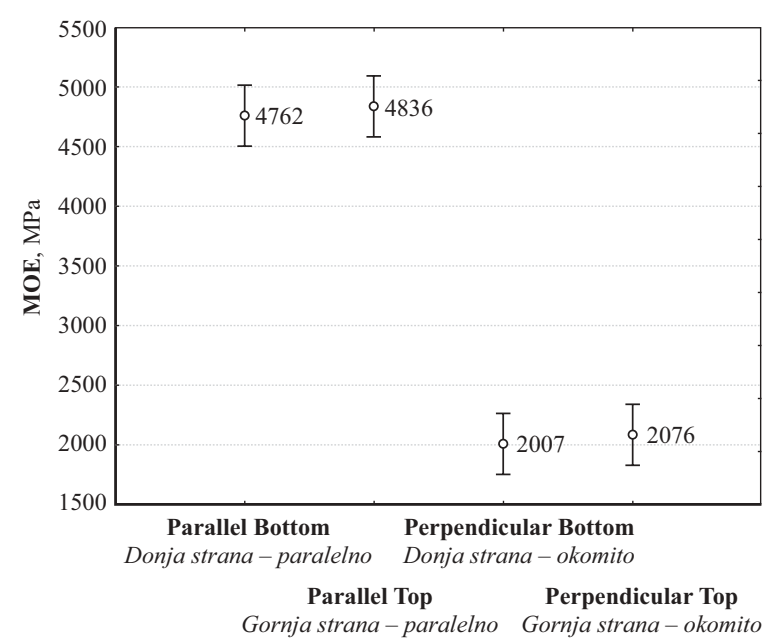

Figure 2 The values of the modulus of elasticity in bending for individual specimen groups (ANOVA - vertical bars denote 0.95 confidence intervals)

Slika 2. Vrijednosti modula savojne elastičnosti za svaku skupinu uzoraka (ANOVA - vertikalne duljine označavaju 0,95 intervala pouzdanosti)

deflection of construction materials causes some higher force moments, and the overall construction is more likely to be damaged. Due to the rheological properties of wood and the irreversible changes induced by a change of humidity inside the OSB, the larger deflection is a disadvantage, not only from the viewpoint of the stress to be accepted but also from the viewpoint of deteriorated use properties.

As has already been proven in previous studies (Suchsland, 1968), the strength of the strand panels is influenced by the strength of the individual contact areas of chips to be bonded. Larger chips increase the overlapping factor, and thus the adhesive transfers a higher force. The different size of chips (and partly the more random orientation of wood elements in the lower face) may explain the different values of modulus of elasticity in bending between the lower and upper faces of the OSB. Therefore, the differences with regard to
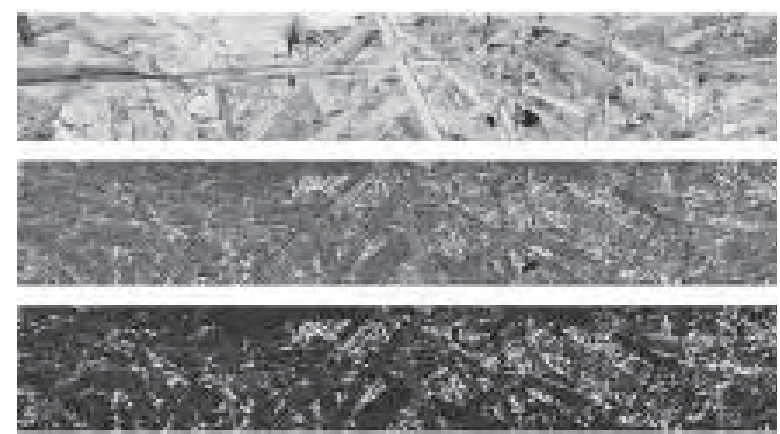

Figure 4 OSB/3 - Superfinish, parallel direction - lower face. Top-down: raster image scanned, vectorized image; image created by means of the „Threshold“ function (the white color stands for clearances between the chips within the surface layer)

Slika 4. OSB/3 - izvrsne završne obrade, paralelni smjer donja strana; odozgo prema dolje slijedi skenirana rasterska slika koja je vektorizirana, a na dnu je slika nastala primjenon funkcije „Threshold“ (bijela boja označava zračnost između iverja u površinskom sloju)

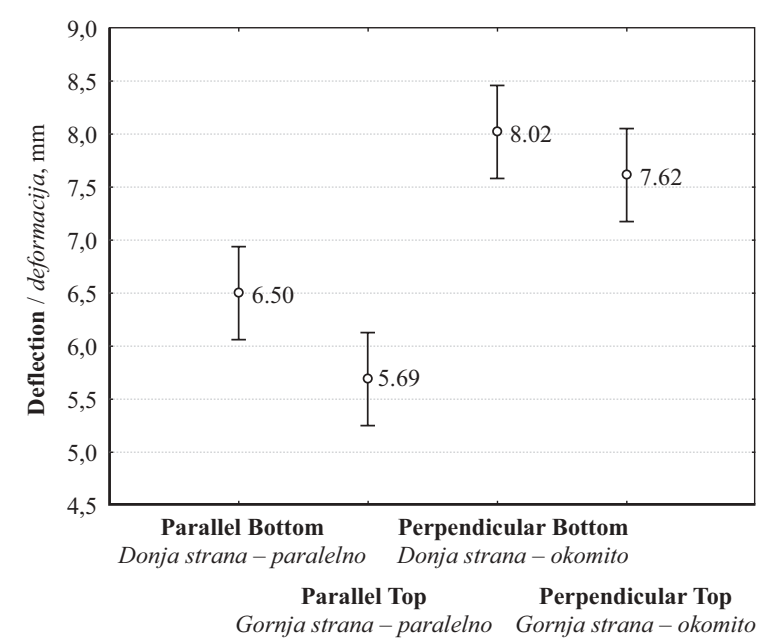

Figure 3: Maximum deflection under load (ANOVA vertical bars denote 0.95 confidence intervals) Slika 3. Maksimalna deformacija pod opterećenjem (ANOVA - vertikalne duljine označavaju 0,95 intervala pouzdanosti)

quantity and size of chips in the lower and upper faces of the panels were analyzed (see Figures 4 and 5).

For the parallel direction, the average quantity of wood particles in the lower surface layer of the OSB was $6.7 \%$ higher in comparison with the upper face, but the average size of the wood particles in the lower face was $1.6 \%$ smaller than in the upper face. For the perpendicular direction, the average quantity of wood particles in the lower surface layer of the OSB was $16.2 \%$ higher, and their size was $1.5 \%$ smaller than in the upper face of the OSB.

\section{CONCLUSION \\ 4. ZAKLJUČAK}

OSB is a state-of-the-art material that - although manufactured from low-quality raw materials - does provide very good mechanical properties, which make

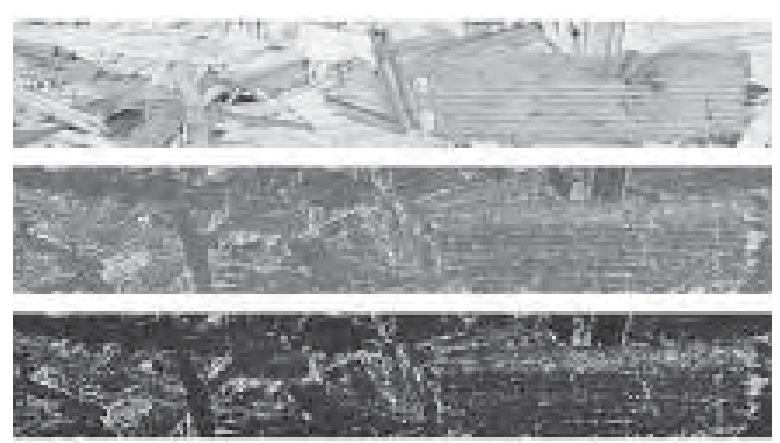

Figure 5 OSB $/ 3$ - Superfinish, parallel direction - upper face. Top-down: raster image scanned, vectorized image; image created by means of the „Threshold“ function (the white color stands for clearances between the chips within the surface layer)

Slika 5. OSB/3 - izvrsne završne obrade, paralelni smjer gornja strana; odozgo prema dolje slijedi skenirana rasterska slika koja je vektorizirana, a na dnu je slika nastala primjenom funkcije „Threshold“ (bijela boja označava zračnost između iverja u površinskom sloju) 
it suitable to be used in the building industry. In order to use the advantageous properties of this material even more efficiently, OSB should be placed with the upper face downwards so as to withstand bending loads (floors, roofs, etc.). The characteristic properties of this material will thereby be used more efficiently, the resulting constructions will be of a higher strength, and a lower deflection under load will be achieved.

Furthermore, using OSB with the upper face downwards is advantageous because of the relatively high variability in the values of modulus of elasticity in bending (15.4 to $25.9 \%$ in the parallel direction). Test specimens whose surface layers included large chips achieved - within the testing groups - some significantly higher MOE values in comparison with specimens having surface layers containing larger quantities of smaller chips. Thus the size and quantity of the chips in the surface layer are significant factors influencing the modulus of elasticity in bending, as well as the deflection, primarily because wood-based materials loaded by bending are broken mostly on the lower face of the test specimen under tension.

Current standards ruling the determination of modulus of elasticity in bending use the know-how of the manufacturing of strand panels but are not appropriate for evaluating the properties of OSB. For determining the modulus of elasticity in bending, one half of the test specimens were placed with the lower face downwards and the other half with the lower face upwards. This procedure is sufficient to determine the quality of the bonding (in accordance with the ČSN EN 310 standard); however, it is less appropriate for determining the characteristic properties of building materials (in accordance with the CSN EN 789 standards) to be expressed within the $5 \%$ percentile. Although the variation in the properties of the upper and lower faces of the panels is just on the limit of statistical determination, it is significant enough to generally place all OSB test specimens with lower face downwards. Reaching the lower $5 \%$ percentile more objectively will thereby be secured.

\section{Acknowledgments - Zahvala}

This work was supported by the Internal Grant Agency of the Czech University of Life Sciences in Prague (Grant No. 4323013123108).

\section{REFERENCES}

\section{LITERATURA}

1. Baker, W. A., 2002: Wood Structural Panels. In: Williamson, T. G.: Wood Handbook, APA - The Engineered Wood Association. N.Y., McGraw-Hill Companies, Inc.

2. Geimer, R. L., 1986: Mechanical Property Ratios: A Measure of Flake Alignment. Research Paper FPL 468, USDA, Forest Products Laboratory, Madison.

3. Han, G.; Wu, Q.; Lu, J. Z., 2006: Selected properties of wood strand and oriented strandboard from small-diameter southern pine. Wood and Fiber Science, 38 (4): 621-632.

4. Han, G.; Wu, Q.; Lu, J. Z., 2007: The influence of fines content and panel density on properties of mixed hardwood oriented strandboard. Wood and Fiber Science, 39 (1): 2-15.
5. Kamke, F. A., 2004: Physics of hot pressing. General Technical Report, Forest Products Laboratory, USDA Forest Service FPL-GTR-149: 3-18.

6. Lam, F., 2001: Modern structural wood products. Progress in Structural Engineering and Materials, 4 (3): 238245. doi:10.1002/pse.79

7. Nishimura, T.; Ansell, M. P., 2002: Monitoring fiber orientation in OSB during production using filtered image analysis. Wood Science and Technology, 36: 229-239. doi:10.1007/s00226-001-0126-0

8. Nishimura, T.; Ansell, M. P.; Amin, J., 2004: Image analysis and bending properties of model OSB panels as a function of strand distribution, shape and size. Wood Science and Technology, 38: 297-309. doi:10.1007/s00226-003-0219-z

9. Oudjehane, A.; Lam, F.; Avramidis, S., 1998: Forming and pressing processes of random and oriented wood composite mats. Composites Part B (29B): 211-215.

10. Painter, G.; Husman, H.; Pritzker, M., 2006a: Prediction of oriented strand board properties from mat formation and compression operating conditions. Part 1. Horizontal density distribution and vertical density profile. Wood Science and Technology, 40: 139-158. doi:10.1007/s00226-005-0044-7

11. Painter, G.; Husman, H.; Pritzker, M., 2006 ${ }^{\text {b }}$ Prediction of oriented strand board properties from mat formation and compression operating conditions. Part 2: MOE prediction and process optimization. Wood Science and Technology, 40: 291-307. doi:10.1007/s00226-005-0050-9

12. Peña, S. V.; Rojas, I. M., 2006: Tecnología de la madera ( $3^{a}$ edición). Artes Gráficas Cuesta, S.L., Madrid.

13. Sharma, V.; Sharon, A., 1993: Optimal orientation of Flakes in oriented strand board (OSB). Experimental Mechanics, June 1993: 91-98. doi:10.1007/BF02322483

14. Suchsland, O., 1968: Particle-board from Southern Pine. Southern Lumberman. December (15): 139-144.

15. Štefka, V., 2002: Kompozitné drevné materiály II, Technológia aglomerovaných materiálov. Technická univerzita, Zvolen.

16. $\mathrm{Xu}, \mathrm{W} ., 1999$ : Influence of vertical density distribution on bending modulus of elasticity of wood composite panels: A theoretical consideration. Wood and Fiber Science, 31 (3): 277-282.

17. Xu, W., 2002: How to analyze strand alignment of oriented strandboard. Forest Products Journal, 52 (4): 48-52.

18. Xu, W.; Winistorfer, P. M., 1995: A procedure to determine thickness swell distribution in wood composite panels. Wood and Fibre Science, 27 (2): 119-125.

19. *** ČSN EN 300 (2006): Oriented Strand Boards (OSB) - Definitions, classification and specifications.

20. *** ČSN EN 310 (1995): Wood-based panels - Determination of modulus of elasticity in bending and of bending strength.

21. *** CSN EN 326-1 (1997): Boards of wood. Sampling, cutting and inspection. Part 1: Sampling, cutting specimens and the formulation of test results.

22. *** ČSN EN 789 (2005): Timber structures - Test methods - Determination of mechanical properties of wood based panels.

\section{Corresponding author}

Ing. MARTIN BÖHM, Ph.D.

Czech University of Life Sciences Prague

Faculty of Forestry and Wood Sciences

Department of Wood Processing

Kamycka Str. 1176

16521 Prague 6, CZECH REPUBLIC

e-mail: bohm@fld.czu.cz 